\title{
Cervicovaginal Secretion
}

National Cancer Institute

\section{Source}

National Cancer Institute. Cervicovaginal Secretion. NCI Thesaurus. Code C150892.

The watery fluid, consisting of vulvar gland, endometrium, and oviduct secretions, cervical mucus, vaginal wall plasma transudate, exfoliated cells, and bacterial and immune cell products, that hydrates and forms an antimicrobial barrier for the mucosa of the lower female genital tract. 